\title{
Legal Protection of Indonesian Nurses in Japan
}

\author{
Soekotjo Hardiwinoto ${ }^{1}$, Darminto Hartono ${ }^{2}$, Muchsin Idris ${ }^{3}$ \\ \{soekotjo.hardiwinoto@yahoo.com ${ }^{1}$, darmintohart@gmail.com², muchsin_i@gmail.com ${ }^{3}$ \} \\ ${ }^{1,2,3}$ Diponegoro University, Jl.Prof. H. Soedarto, S.H. Tembalang, Tembalang, Kota Semarang, Jawa \\ Tengah, 50275, Indonesia
}

\begin{abstract}
Legal Protection of Indonesian Nurses in Japan is legally binding protection provided by the State with the guidance of its regulations. Indonesian Nurses, as the subject of law, are the rights and obligations holder under the law. Their rights are to get legal protection with the regulations in force, while their obligations are to must fulfill requirements decided by the Japan Government (where they work). The research aims to focus on how to conduct an inventory of the regulations for the Indonesian Nurses legal protection and what efforts are needed by the Indonesian Government in addressing the problem of nurses who do not understand the legal protection rules. The method uses descriptive research with a qualitative approach through the method of normative juridical approach and data analysis method. These research results show that the Indonesian nurse's legal protection is in the provisions of laws on civil protection; namely Indonesian Law, Japanese Law, and applicable International Law. It is done before their departure to Japan when they work in Japan, and after they return to Indonesia. The National Agency for Placement and Protection of Indonesian Migrant Workers as the representative of Government has the functions and duties to offer legal protection to Indonesian nurses, who are obliged to guide and control to the officer to be ideal and to better understand the rules of law on their protection that will lead to coordinate and informative efforts between officials and nurses. The Indonesian nurse's legal protection implementations have not met the expectations.
\end{abstract}

Keywords: Migrant Workers, Legal Protection, Indonesian Nurses, Japan

\section{Introduction}

The relationship between Indonesia and Japan has been going on for a long time through cooperation in various fields. IJEPA (Indonesia-Japan Economic Partnership Agreement) in 2008 is one of cooperation between the Republic of Indonesia and Japan on an economic partnership agreement in bilateral economic cooperation. The agreement has agreed on the benefit of both parties in a balanced and measured manner through the liberalization of market access, facilitation, and cooperation through the development of priority industry sectors. [1]

Legal basis of Indonesian Nurses to Japan is IJEPA- Trade-in Service. The National Agency conducts the Indonesian Nurses management working in Japan for Placement and Protection of Indonesian Migrant Workers. The term "Nurse" as used in this Act means a person under licensure from the Minister of Health, Labor, and Welfare to provide medical treatment or assist in medical care for injured and ill persons or puerperal women, as a profession[2]. Indonesian Nurses, as the subject of law, are the rights and obligations holder under the law. Their rights are to get legal protection with the regulations in force, while their obligations are to must fulfill requirements decided by the Japan Government where they work. 
According to Sadako Yoshimura in Legal Responsibilities of Nurses in Japan, that nurses need hopefully to continually update their nursing expertise and skills to remain abreast of the advancements in medical care. This includes the mastery of new electronic devices that enable nurses to make more sophisticated observations of patients. It is also necessary for nurses to provide higher standards of care to protect the patient's health[3].

It makes it difficult for Indonesian nurses considering the obstacles that must be faced, and they should be prepared as well as possible before going to Japan.

Indonesian Nurses are Indonesian citizens who work in Japan for a certain period based on the agreement between Indonesia and Japan through Government to Government system. One of the points contained in IJEPA is demand for Indonesian nurses by the Japanese Government and its sent by the Indonesia Government, which was then followed by the signing of a Memorandum of Understanding (MoU) between National Agency for Placement and Protection of Indonesian Workers and Japan International Corporation of Welfare Services on 19 May 2008 in Jakarta[4].

Jobseeker opportunities for employment should be opened for all parties to meet the need for several workers according to skill classification and utilization of the potential workforce.

The Indonesia Government's efforts to find alternative solutions in order to improve the quality of the young generation and to reduce the more significant number of unemployment is by issuing the Policy of Placement of Indonesian Migrant Workers Abroad, which increase the foreign exchange revenue of the State. For the Indonesian Workers themselves, this is an attraction to get the opportunity of increased skills and job training abroad in the hope of pursuing a better life in the future.

National Agency for Placement and Protection of Indonesian Workers and the Ministry of Manpower as the party that guarantees the protection of Indonesian Nurses in Japan tried to overcome the negative things caused by various parties in the legal protection of Indonesian Nurses. There is a tendency to emerge various issues that must be addressed as follows: How to conduct an inventory of the regulations for the Indonesian Nurses legal protection; What efforts are needed by the Indonesian Government in addressing the problem of nurses who do not understand the legal protection rules.

\section{Method}

The research on Legal Protection of Indonesian Nurses in Japan is legally binding protection provided by the State with the guidance of the regulations. This study uses the method of normative juridical approach and data analysis method.

It uses descriptive analysis method by using the literature, documentary study, and field research related to the primary substance of the study. After the data have been collected, the next process is to identify, to clarify, and to analyze systematically. Finally, all research results are presented in a compiled final report.

\section{Findings}

\subsection{General Overview of the Japan Economic and Social Culture}

Japan is a small archipelagic state lacking in natural resources, with a population of more than 128 million. Despite the conditions that constrained these developments and the collapse of its industrial structures during World War II, Japan has not only succeeded in 
rebuilding its economy but also become one of the world's leading industrialized nations today[5].

The purpose of Japan's economic cooperation is to help developing countries to raise their economic level and achieve higher living standards for their people.

Japan can prosper and live only in a world built on mutual dependence with other nations. Since 1965, the growth of the Japanese population has decreased, namely the decline in the birth rate, which has led to decreased rates of increase in the productive age population. If this trend continues, the Japanese will gradually face issues like an increasingly aging workforce, with few young workers and an ever-increasing need to provide care for the elderly.

According to Professor Hiroshi Yoshida, economic expert Tohoku University, Japan, as published in the Daily Mail, May 14, 2012, stated that[6] : birth rate began to show an alarming decline since 1975. The number of births shows that the population of children up the 14-year-old currently stands at 16.6 million, and that shrinks by one (1) every 100 seconds. Recent studies show that if such condition is allowed to continue, the Japanese population is expected to become extinct within 1000 years.

"If the birth rate continues to decline, the long Day Children Day on May 5, 3011 will only be celebrated by a child. One hundred seconds later, there will be no more children left."

Different geographic conditions between Japan and Indonesia will result in many obstacles for Indonesian Nurses. Japan is a sub-tropical country with four (4) seasons, Winter (Fuyu), Spring (Haru), Summer (Natsu) and Autumn (Aki), while Indonesia is a tropical country with two (2) seasons. Besides, Japan, as a developed industrial country, has a much different lifestyle from Indonesia as a developing country, so it is very influential on Indonesian Nurses with different cultures and languages. The work ethic of Japanese people who always put the quality of professionalism and teamwork with high spirits, discipline, and time will make the Indonesian Nurses must be able to adjust to it quickly.

\subsection{Legal Protection of Indonesian Nurses.}

According to Supomo, labor protection is divided into three (3) types, namely[7]:

a. Economical protection

The labor protection in the form of sufficient income, including if the labor is not able to work beyond their will.

b. Social protection

The labor protection in the form of health insurance and freedom to join the association and the right protection to the organization.

c. Technical protection

The labor protection in security forms and work safety.

While the object of labor protection according to Act of Indonesia \# 13 2003, covering:
a. The protection of rights in job relations;
b. Occupational safety and health protection;
c. Special protection for women, children, and people with disabilities;
d. Protection of wages, welfare, and social security of labor; and 
e. Protection of employment termination rights.

The protection forms of the functions of diplomatic and consular officials can be realized in accordance with its function, namely:

a. Technical Protection: The technical protection measures that can be performed by the diplomatic representatives of the Republic of Indonesia are actions directed to Indonesian Nurses in the form of providing safe shelters and repatriation and, if necessary, the Embassy can be a facilitator by rehabilitating the troubled Indonesian Nurses.

b. Juridical Protection

1) In providing legal protection to Indonesian citizens abroad, the Diplomatic Representative of Indonesia will provide legal consultation assistance in the form of Representative of the Republic of Indonesia work closely with lawyers giving directives to the citizens who will face legal proceedings.

2) They are related to the amount, the protection and legal assistance required special attention to the troubled Indonesian Nurses. Consular Affairs, in collaboration with other technical fields, may assist with the remedies by way of consensus or through legal channels.

c. Political protection provided using the bilateral agreements on the placement and protection of Indonesian Nurses is indispensable in order to optimize the protection of Indonesian Nurses.

\subsection{Indonesian Nursery Rights and Obligation}

The Basic Implementation of the Laws Regulating about Indonesian Nurses is operational:

a. The provisions of the rules of International Law

Protection of the rights and obligations of workers is available in the provisions of the International Convention, but the problems of migrant workers cases are still emerging and have not been fully implemented, especially those related to the abandonment and violation of the rights of migrant workers. The regulations related with migrant workers are ILO Convention \#97/1949; ILO Convention \#143/1975; UN Resolution \#45/158; Universal Declaration of Human Rights; Vienna Convention 1961; Vienna Convention 1963.

b. The provisions of the Japan National Law

Japan, as the recipient state of Indonesian nurses to the territory, will grant the visa where the visa is obtained. The Indonesian nurse personnel through the Japanese Embassy in Indonesia will soon give rise to certain rights and obligations. Indonesian nurses receive the right of recipient state revenue, but they must comply with laws and regulations. This is called the term temporary compliance. The regulations related with Indonesian Nurses are Labor Law (Roudou Kijunbi) Japan, 1946; Unions Act (Roudou Kijunhou) Japan, 1949; The Labor Standards Act (Roudou Kijunhou) Japan, 1947, amended in 2003; Immigration Control Act, 1990; Japan Constitution, May 3rd, 1947.

c. The provisions of the Indonesia National Law

In Article 28, C (1), Indonesia Constitutional Law 1945 stated that: 
"Every person shall have the right to develop himself through the fulfillment of his basic needs, deserve an education and benefit from science and technology, art and culture, to improve the quality of his life and for the welfare of mankind."

Whereas, Article 27 paragraph (2) stated that: "Every citizen has the right to work and earn a decent living for humanity."

(1) Constitution of the Republic of Indonesia 1945;

(2) Act of Indonesia \#9, 1992 concerning on Immigration;

(3) Act of Indonesia \#39, 2004 concerning on Human Rights;

(4) Act of Indonesia \#13, 2003 concerning on Manpower;

(5) Act of Indonesia \#24, 2000 concerning on International Treaties;

(6) Act of Indonesia \# 39, 2004 concerning on Placement and Protection of Indonesian Workers;

(7) The Memorandum of Understanding (MoU) between the 'Binalattas' Directorate General of the Ministry of Manpower and Transmigration with the Association for International Manpower Development of Medium and Small Enterprises Japan (IMM), September 16th, 1994, was amended with an amendment on February 1st, 2010.

\subsection{Problems Faced in Providing Protection for Indonesian Workers Abroad Related to Indonesian Nurses}

There are various issues which can be summarized as follows:

\section{Pre-departure Period}

Recruited illegally by Indonesian Private Labor Dispatch Company or brokers; Forgery of documents; Exactions and discrimination from the government (more expensive rates for migrant workers when managing documents); Training is done with unprofessional and just a formality.

\section{During Working Abroad Period}

The type of work is not in accordance with the employment agreement; Not holding any document because all documents held by employers; Difficulties to communicate because of the different language; Difficulties with the food containing pig and alcohol because of religions ban; Difficulties with the different seasons and the extreme weather; Difficulties to customize the culture and Japanese customs that works hard with a spirit and big will; Attitude apparatus Embassy / Consulate who does not defend or abandon; Settlement of the case is not exhaustive and sent home because of the length of the settlement process; The authorities embassy/consulate imposes charges in overseas under various pretexts.

\section{After Return Period}

Discriminatory treatment at the airport or place other repatriation; Squeezed/collected money by thugs/officers at the airport/port with various pretext; Most of the participants who took the final nursing exam in Japan failed, choose to be a caregiver and forget the knowledge; Indonesian Nurses who are returning to Indonesia, choose to resign from nursing because of low salary and have a good knowledge. 
4. There are various efforts from the Indonesia Government in addressing the issue of Indonesian Workers Overseas, namely:

a. Take firm action to the officer who is intentionally recruiting without clear procedures.

b. Cooperation among the Ministry of Labor, Ministry of Foreign Affairs, Office of Immigration, and Representative / Embassy / Consulate General of the Republic of Indonesia to coordinate an effort to anticipate the counterfeiting documents;

c. Ministry of Foreign Affairs provides continuous information that will be important to report the arrival of migrant workers and their presence in the territory of accreditation of Representative / Embassy / Consulate General of the Republic of Indonesia.

d. Collaboration and coordination between Representative / Embassy / Consulate General of the Republic of Indonesia and Police of the recipient state of migrant workers regarding the presence of migrant workers who have legal problems.

e. Representative/embassy/ Consulate General of the Republic of Indonesia in cooperation with related institutions/organizations, in terms of repatriation of troubled migrant workers in state-financed.

\section{Conclusion}

IJEPA Cooperation in the field of Indonesian Nurses is a requirement of reciprocity, Japan's lack of productive labor and Indonesia has the human resources abundant productive age. Indonesian Nurses Concepts in Japan is working on job training apprenticeship program to prepare a skilled workforce, who are competent and productive to be developed after returning to Indonesia for a higher quality of life in the future.

Recipient companies or institutions in Japan have high authority so that Indonesian Nurses should quickly be able to adjust to the Japanese customary life inevitably. The recipient company's rights and obligations are getting Indonesian Nurses by the requirements that have been determined jointly and obligations to provide technical, political, and legal protection to them.

Every citizen has the right to education and a decent job with a salary by the level of competence and professional manner. Migrant workers have entitled to protection from the government and also the protection of the recipient state government. The Government who has the functions and duties to offer legal protection to Indonesian nurses are obliged to guide and control the officer to be ideal and to better understand the rules of law on their protection that will lead to coordinate and informative efforts between officials and nurses. The Indonesian nurse's legal protection implementations still have not met the expectations.

The Indonesian nurse's legal protection is in the provisions of laws on civil protection, namely Indonesian Law, Japanese Law, and applicable International Law. It is done before their departure, while they work in Japan, and after they return to Indonesia.

\section{References}

[1] R.; S. D. Kurniasari, "Analysis of Indonesia Japan Economic Partnership Agreement (IJ-EPA) Towards Textile Export Value at PT Argo Pantes Tbk (Period 2009-2013)," Int. J. Acad. Res. Dev., vol. 3, no. 1, pp. 1175-1184, 2018. 
[2] R. Sakuraba, "The Amendment of The Employment Measure Act: Japanese AntiAge Discrimination Law,” Japan Labour Rev., vol. 6, no. 2, pp. 56-75, 2009.

[3] S. Yoshimura, "Legal Responsibilities of Nurses in Japan: Through Recent Law Cases," J. Compr. Nurs. Res., vol. 2, no. 1, pp. 48-55, 1999.

[4] E. . . [et. al. F, "IJEPA: Gray Area for Health Policy and International Nurse Migration," Nurs. Ethics, vol. 24, no. 3, pp. 313-328, 2015.

[5] N. and H. A. Muratmasu, "Japan: Super- Aging Society Preparing for the Future," Gerontologist, vol. 51, no. 4, pp. 425-432, 2017.

[6] V.; B. A. and M. P. Balaji, "Population Explosion and Implosion- An Overview International," J. Eng. Manag. Res., vol. 11, no. 2, pp. 1-13, 2012.

[7] A. Khakim, Dasar-Dasar Hukum Ketenagakerjaan Indonesia. Bandung: Citra Aditya Bhakti, 2009. 